\title{
Constraints Facing Women Entrepreneurs In Kenya:A Case Study OfMicro And Small Enterprisesin Kisii County
}

\author{
Kepha Osoro ${ }^{1}$,Abel Mokoro ${ }^{2}$ Douglas Nyamongo ${ }^{3}$ James Areba $^{4}$ \\ 1 KephaMomanyiOsoroJomo Kenyatta University of Agriculture and Technology Kisii CBD Campus P.o Box 268-40200 \\ Kisii \\ 2 Abel MokoroKisii University P.o Box 408-40200 Kisii \\ 3 Douglas NyamongoJomo Kenyatta University of Agriculture and Technology Kisii CBD Campus P.o Box 268-40200 Kisii \\ 4 James ArebaJomo Kenyatta University of Agriculture and Technology Kisii CBD Campus P.o Box 268-40200 Kisii
}

\begin{abstract}
Micro and Small Enterprises (MSEs) are acknowledged in Kenya as significant contributors to economic growth and are estimated to contribute $20 \%$ and $72 \%$ to the GDP and employment respectively. Despite this, it is estimated that MSEs continue to have a deteriorating performance with 3 in every 5 failing within months of establishment. This research sought to investigate and establish constraints facing women owned enterprises in micro and small enterprises in Western part of Kenya; focusing on Kisii county. The specific objectives were to identify the main constraints to the performance of women entrepreneurs, determine those constraints that uniquely affect women, analyze the influence of the constraints on performance of MSEs. From a population of 2,990 women entrepreneurs engaged in MSEs, a sample of 200 was selected randomly and a survey was conducted on this sample using both structured and un-structured interview schedules. Data from the respondents was analyzed and translated into useful information using percentages and the statistical package for social sciences (SPSS). Frequency distributions and tables were used to draw conclusions. Main constraints identified were: lack of finance, legal constraints and lack of security/collateral. Women entrepreneurs cope with these constraints by diversifying in business and training. The study concluded that despite the many constraints that they face, women entrepreneurs operating in MSEs have the potential to perform better and grow. The results of this study are expected to assist the Kisii County Government and stakeholders to formulate and implement appropriate policies and interventions aimed at developing and empowering women operating in MSE entrepreneurs in this region.
\end{abstract}

Key Terms: Gender;Constraints; Micro and Small Enterprises; Entrepreneur; Performance

\section{Introduction}

\section{Introduction}

This chapter contains the background to the study, statement of the problem, research objectives and research questions, significance of the study, the scope and the limitations.

\section{Background to the Study}

Kisii County is a densely populated area in Nyanza Province in Western Kenya and is characterized by high rainfall throughout the year with rich agricultural activities. Kisii Town is located in south western Kenya, is the main urban and commercial hub in South Nyanza Area. It's characterized by open markets, street traders, hawkers and several other entrepreneurial ventures.

Micro and small-scale enterprises (MSEs) play an important role in the Kenyan economy and are accorded high priority in the development policy (GOK, 2008) ${ }^{1}$. Despite this, it is estimated that MSEs continue to have a deteriorating performance with 3 in every 5 failing within months of establishment. Research findings show that many do not celebrate their third birthday.

Findings from the 1999 MSEs Baseline Survey (CBS, et al.,1999) showed that there were a total of 1.3 million enterprises employing some 2.4 million people and contributed over $75 \%$ of all new jobs created in the country. In addition, the MSEs contributed over $57 \%$ of the new jobs created in 2005/2006 (GoK, 2007) and $79.8 \%$ of total employment in 2008 (GoK, 2009) ${ }^{4}$. Women as micro and small entrepreneurs have increasingly become the key target group for micro finance programs. Consequently, providing access to micro finance facilities is not only considered a pre-condition for poverty alleviation, but also considered as a strategy for empowering women (Karanja, 1996).

It is expected that by the year 2030, Kenya will be transformed into a newly industrialized nation. If the country has to make this leap, then the small enterprises are expected to play a key role in this transformation. It is also noteworthy that most of the businesses in this sector remain micro, employing less than fivepeople and 
having such a high mortality rate as such, hence the firms hardly graduate into large or even mediumorganizations.

In Tanzania, the full potential of the SME sector has yet to be tapped due to the existence of a number of constraints hampering the development of the sector. They include: unfavourable legal and regulatory framework, undeveloped infrastructure, poor business development services, limited access of SMEs to finance, ineffective and poorly coordinated institutional supportframework etc.

Lack of planning, improper financing and poor management have been posited as the main causes of failure of small enterprises (Longenecker, et al., 2006). Lack of credit has also been identified as one of the most serious constraints facing SSEs and hindering their development (Oketch, 2000).

Whereas a mix of political, economic and social strategies are needed to bring about the required changes, there is a general consensus that development of micro and small enterprises constitutes one of the main pillars in this endeavor as they are expected to serve as the breeding ground or seedbed from which large firms will emerge. For this and other reasons, donor communities, private sector organizations and the government have continually provided financial and technical support to micro and small enterprises. In addition, a number of related efforts and support interventions have been directed towards this sector to enable it to create job opportunities, which will improve the overall economy and assist in poverty reduction.

This study therefore sought to undertake, a survey of the constraints facing Kenya women entrepreneurs operating micro and small-scale enterprises. The focus of the study was on constraints that limit the performance, hence growth of MSEs and their transition into medium and large scale enterprises. In addition, this study sought to identify specific constraints experienced by the women MSE entrepreneurs.

\section{Statement of the Problem}

The contribution of women entrepreneurs to the economic development has not been adequately highlighted. MSEs are generally regarded as the driving force of economic growth, job creation, and poverty reduction in developing countries. While the contributions of MSEs to development are generally acknowledged, women entrepreneurs face many constraints that limit their long-term survival and development. Scholars have indicated that starting a business is a risky venture and warn that the chances of entrepreneurs operating MSEs making it past the five-year mark are very slim. (Kepha, 2013 ${ }^{10}$ ) It is also essential to understand the constraints facing MSEs development in Kenya because they are significantly different from those facing developed countries. These constraints include limited access to financial resources, legal constraints, and poverty that has led to lack of security

Lack of adequate collateral to give as security, strict legal framework on women especially those not married and many requirements from financial institutions on women as regards their husbands have been touted as major drawbacks in the growth and development of the women entrepreneurs in the MSE sector. This is despite assertions that effective provision of financial assistance from the government does enhance productivity and competitiveness of the MSEs.

Therefore the purpose of this study will be to determine and identify the constraints affecting women entrepreneurs in seeking financial support, lack of security and collateral due to a male dominated society that is taught right from child birth and how their provision can influence the performance of MSEs.

\section{Objectives}

This study aimed at examining the constraints to performance of the women entrepreneurs in the MSEs in Kisii County, with the following specific objectives:

a) To determine the constraints faced by women entrepreneurs in MSEs in Kisii county.

b) To analyze the influence of the constraints on the performance of women entrepreneurs in the MSEs in Kisii county

c) To examine how women entrepreneurs cope with to the constraints facing them in the MSEs sector in Kisii county.

\section{Research Questions}

i) What are the constraints that women entrepreneurs face in MSEs in Kisii County?

ii) How do the constraints affect the performance of Women entrepreneurs in Kisii County?

iii) How do these women entrepreneurs respond to the constraints facing them in MSEs sector in Kisii County?

\section{Justification}

This study was important in that the county government shall use the findings from this study to get direction on how to prioritize its expenditure of the funds and policy makers in consideration to areas where job creation and other strategies should be focused in promoting MSE growth. 
The Kenyan government in its efforts to promote the enterprise culture amongst the Kenyan populace especially the women entrepreneurs as a means of encouraging self-employment will find the results of this study useful in formulating regulatory policies on the provision of business services through its agencies such as Uwezo Fund, Youth Enterprise Fund and Women Enterprise fund. Further, in a globalized economy, there is increasing recognition that identifying the constraints facing MSEs may be meaningful in terms of the types of intervention from the developed countries may provide. Information regarding the operations and constraints of MSEs is still needed by different sectors of the economy and thus this study served to generate information on the status of entrepreneurs operating in MSEs.

It is also hoped that this study will add to the available body of knowledge in MSEs and increase the understanding of how to best help women entrepreneurs in the MSEs sector, so that they may contribute positively to economic development of Kisii County and Kenya in general.

Scope.

This study was limited to small and micro enterprises owned by women in Keroka market, Suneka market and darajaMbili market within Kisii County.

\section{Introduction}

\section{Literature Review}

This chapter reviews the past literature on the subject under the study, in specific it shall look at theoretical review, performance of MSEs, Empirical review, conceptual framework

This study investigated the constraints facing women entrepreneurs operating in Small and Micro Enterprises in the in Kisii County.

\section{Studies and Development of MSEs}

Entrepreneurship has its origin from the French word entreprendrethat means "to undertake" Burch (1986). Lazear (2005: 649) defines entrepreneurship as "the process of assembling necessary factors of production consisting of human, physical, and information resources and doing so in an efficient manner" and entrepreneurs as those who "put people together in particular ways and combine them with physical capital and ideas to create a new product or to produce an existing." Entrepreneurship is considered as a factor of production, linked to innovation and risk taking, where entrepreneurial compensations are tied to uncertainty and profits (Montanye, 2006). The entrepreneur brings changes into an existing 'equilibrium' of a circular flow of goods and services, further argued Schumpeter. The entrepreneur comes up with new strategies that could improve the market place and lead to the growth of the enterprises.

In the United States of America, the Small Business Administration (SBA) defines MSEs in terms of the number of employees, total assets and annual sales of the enterprise. Enterprises are called small family businesses if they have four or fewer employees, with an annual sales turnover of USD 499 or less, while those having 5 to 9 employees with an annual sales turnover from USD 500 to USD 2,499 are classified as small enterprises

In China, MSEs are referred to as 'small-scale sector' with no sub classification of the very small family businesses, and defined as those enterprises employing less than 100 workers. However in India, those enterprises with a fixed capital less than Rs 500,000 are referred to as tiny enterprises while small enterprises are those having a fixed capital investment of between Rs 500,000 and Rs 6,000,000 (Islam1996).

Ghana considers firms with less than 10 employees as small scale enterprises while the World Bank defines small scale enterprises as firms with fixed assets (excluding land) of less than USD 250,000 in value.

\section{Constraints Facing Micro and Small Enterprises}

The entrepreneurs of MSEs not only create income and employment, but they also generate wealth and contribute to the welfare of a Nation's population in the long run. MSEs in developing countries are however confronted with several drawbacks and challenges that they have to overcome in order to operate successfully. Major obstacles include access to finance (Arthur, 2003), legal constraints and lack of security and collateral. In order to strengthen the position of MSEs, both financial and non-financial constraints, need to be addressed if the entrepreneurs are to improve their performance and hence contribute more meaningfully to society.

According to UNIDO (2003), constraints related to institutions include: access to formal training, lack of skills and managerial expertise, lack of formal schooling, limited access to property rights, limited access to credit, excessive government regulations, lack of information on prices, markets and viability of the products and lastly, fewer market opportunities due, for instance, to non-compliance to international standards.

Commenting on financial constraints, Keshap (2008) whose findings are based on a study of twelve states in India, states that the prevailing situation has been much more difficult for the micro and small enterprise sector. A particular problem facing MSEs is limited access to capital, especially the lack of 
transparency regarding the financial conditions of SMEs. Further, Keshap (2008) stated that unless fairly detailed information on MSEs was available, banks would hesitate to take the risk of financing them

\section{Constraints Facing Micro and Small Enterprises in Kisii County}

Gender differences are enshrined in the Kisii county culture where the role of the family is either that of a wife or a mother. Employers give priority to males, in employment and promotion, even if women command higher merits. Women, despite their interest, lack work opportunities and represent only a small percentage of the labor force. This region of western Kenya is a male dominated society that is taught right from child birth.

Majority of businesses in Kenya are small and micro enterprises with less than 10 employees, while 70 percent of them are one person operated. The Kenya Labour Force Survey Report (GOK Labour Force Survey, 2003) indicates that the sector covers all semi-organized and unregulated activities that are small scale in terms of employment. The report notes that the activities are largely undertaken by self employed persons, singularly or with very few workers, in the open markets, in market stalls, in both developed and undeveloped premises, in residential houses or on street pavements.

The Government of Kenya also recognizes the important contribution of the informal sector to the country's industrialization process. The generation of employment leads to the reduction of unemployment problems and is the primary means of strengthening the country's economy (GOK, 1997). If the objective to industrialize by the year 2020 and Vision 2030 is to be achieved, then the Kenya government has the obligation to encourage the micro and small enterprises sector to play a major role in providing additional jobs. In particular, more effort needs to be directed to developing the largely underestimated and underutilized potential of women entrepreneurs.

It further showed that women entrepreneurs had lower levels of education than their male counterparts, and that about $10 \%$ of all the entrepreneurs had no formal education. These findings are corroborated by Wegulo (1998) whose results showed that comparatively, men operators in MSEs had higher educational attainment than their women counterparts, and that a number of operators had no formal education at all.

\section{Lack of Collateral Constraint}

This study investigated the collateral constraint by women in Kisii County had during their respective business start-up. Women respondents claimed to have experienced lack of security when seeking for services from financial institutions, local authorities and other government departments. In particular, married women felt discriminated upon whenever approval by their husbands was demanded.

It was observed that in a set-up of most Kenyan communities, property is traditionally registered in the husband's name. This, the women claimed, subjected them to 'beg' their husbands for approval especially if in need of collateral. This concern was confirmed by the micro credit officer at Kenya Commercial Bank Kisii Branch that there is such a policy requirement of husband's approval before loans were granted to married women.

This complicated easy access to finance and most women have had to do with their savings, if any, or depend on the husbands. The situation is similar for unmarried women who had to rely on their savings or parent's support for collateral. In a majority of cases, this meant that women had to do with limited capital to start their respective businesses. It is not surprising therefore that most of the women entrepreneurs predominantly venture into service-oriented businesses such as: selling vegetables, fruits, grains, foods and drinks, dress making/tailoring/embroidery/knitting, selling clothes, hair care and retail of consumer goods. Women, especially those with dependents had to balance their responsibilities between business and domestic chores. This led to their working in their businesses for relatively shorter hours, as compared to their male counterparts, which in turn resulted to relatively lower returns. Thus the women entrepreneurs felt that their businesses were more constrained due to the numerous responsibilities and traditional conduct expected of them by society.

The existence of these women entrepreneurs' constraints may thwart the economic potential of women entrepreneurs as such barriers have an adverse impact on enterprise development, productivity, and competitiveness (Bardasi, et al., 2006). Hence it can be assumed that an appreciation of gender issues is important when considering strategies to improve ways for MSE's development in Kisii County.

\section{Legal Constraints}

Contributing to the environmental factors affecting performance of MSEs, Karingithi (1999), states that cumbersome laws and regulations have a negative impact on the growth and development of MSEs because: they absorb scarce management time, increase fixed costs disproportionately, restrict operating flexibility and divert scarce financial resources from productive investment. Edgar Online Inc. (2003) agrees with Karingithi and notes that unfavorable legal framework results in increased general and administrative expenses, and in a diversion of management time and attention from revenue - generating activities to compliance activities. 
According to MItullah (2005), in the absence of a conducive legal framework, businesses operate under the Local Government Act which is restrictive and non responsive to the emerging contributions of SMEs. The provisions of the Act stand in conflict with the Government policy of encouraging the growth and development of MSEs and supporting informal workers. The reforms in the area of business licensing are geared to improving the situation of small enterprises; however, the micro enterprises still face a number of challenges. Harper (1984) observes that governments that are concerned with the promotion of small enterprises should examine the impact of its policies and programmes on the small businesses, Mann et al (1989) makes similar observation that government regulation about wages, taxation, licensing and others are among the important reasons why informal sector business develops. "Without careful attention, government policies could crush the small business sector of any economy" (Strauss, 2006).

It is therefore the government's responsibility to ensure that its policies are helping and not hurting enterprises, creating conditions for the small business to flourish. Licensing, permits and business regulations for instance are major challenges facing small enterprises. While commenting on the need to slash some council licenses Ministry of Trade and Industry P.S, David Nalo observes that many costly permits hamper private sector growth and competitiveness. Some permits and licenses exist for historical reasons while others exist for reasons that are no longer valid.

Harper (1984) also identifies inappropriate standards and legally imposed regulations, which apply to product specification, buildings and environment as some of the other problems facing small entrepreneurs. He notes that such standards are adapted from industrialized countries and for big enterprises hence inappropriate for the small business sector. Taxation has also been ranked high as a source of regulatory cost and disincentive for small businesses in South Africa. According to the article, the tax laws are incomprehensive and complicated to the small businessperson.

\section{Financial Constraint}

Baumback (1988) states that, a major constraint of small business is its inability to obtain adequate financing, either in an absolute sense or because the cost; in terms of interest rates is often prohibitive. He further argues that the high cost of small business borrowing has put considerable pressure on overall small business marginal profits. Kepha (2013) ${ }^{16}$ agrees with Baumback that working capital seems to be a big constraint for many business owners. Oketch (1999); in his studies on MSEs in Nairobi, indicates that lack of credit and finance, whether for working capital, or otherwise, is a major constraint to $32.7 \%$ of firms in the MSE sector. He points out that most MSEs rely primarily or exclusively on own savings and reinvested profits for their business finance.

Kibas and Nelson (1997) in their study of the impact of credit on micro enterprise development in Kenya found out that there were changes in the entrepreneurs' management practices after acquiring loans. The entrepreneurs reported being better planners, organizers, coordinators and managers of time. These improvements were largely attributed to personal discipline developed because of having to utilize the loan more effectively, and the need to repay the loans on time. Wangui (1998) concluded that most MSEs remain small because they lack set missions and objectives, while Eddstone (1993) basing his conclusion on his study on hotels states that the performance of businesses is characterized by weekly, seasonal and business cycles. Kingkaew and Limpaphayom (2001) on the other hand argue that poor record keeping and lack of financial discipline are major contributing factors in business failures. They further state that, low quality and reliability of financial data and the inefficient use of such information to support their financial decision-making, are part of the main problems of SMEs. In the study carried in Nairobi among small manufacturing enterprises, Nyambura (1992) established that finance was rated among the biggest problem. In the study carried in Kisii County recently among small enterprises, Kepha, (2013) established that finance and training from the financial institutions were rated among the biggest problem facing the small enterprises. The problem related to finance includes lack of information on where to source for finance, restrictive lending offered by commercial banks, lack of access to finance, insufficient financing, lack of track record required by the banks, limited access to collateral, and the fact that financial institutions lack appropriate structure for dealing with MSEs.

As a result of scarcity of finance, small enterprises are unable to expand, modernize or meet urgent orders from customers. The profit margins are usually little to support growth. Financeis therefore necessary for the longterm survival and growth of small enterprises. 


\section{Conceptual Framework}

Source: Researcher, (2013)

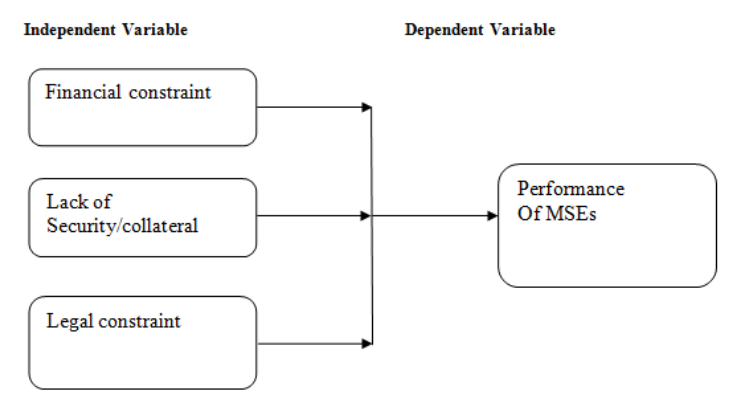

Figure2.1: Conceptual Framework

\section{Entrepreneurs' performance}

Entrepreneurs' performance can be inform of positive changes in sales and increase in profits. In starting and running a new business, the entrepreneur needs finance, security to secure this finance and needs license and pays taxes that needs legal knowledge and thus legal constraint where the entrepreneur lacks the necessary knowledge in handling such information.

It is therefore the government's responsibility to ensure that its policies are helping and not hurting enterprises, creating conditions for the small business to flourish.

Licensing, permits and business regulations for instance are major challenges facing small enterprises. While commenting on the need to slash some council licenses former Ministry of Trade and Industry P.S, David Nalo observes that many costly permits hamper private sector growth and competitiveness. Some permits and licenses exist for historical reasons while others exist for reasons that are no longer valid.

Taxation has also been ranked high as a source of regulatory cost and disincentive for small businesses in South Africa. According to the article, the tax laws are incomprehensive and complicated to the small businessperson. Compliance for such regulations is costly and beyond their capacity. Some of the small business operators prefer operating outside the formal system.

\section{Introduction}

\section{Research Methodology}

This chapter highlights the methodology the adopted by the study. These include research design, the target population and size, the research instruments for the data collection, the sampling technique and method to be used for data analysis. Thestudy investigated constraints facing entrepreneurs in micro and small enterprises in Kisii County.

\section{Study Area} Kenya.

The study was conducted in Kisii County in former Nyanza Province one of forty seven counties in

The women entrepreneurs have a variety of small-scale activities spread across the county, among them food processing, textiles, restaurants, salons and trade. Kisiicounty has a rich agricultural hinterland, well developed formal and informal activities and benefits from a thriving entrepreneurial culture which has given rise to several micro and small scale enterprises.

\section{Research Design}

This was a study of entrepreneurs operating micro and small enterprises in Kisii County. The study was aimed at examining the constraints faced by entrepreneurs operating in the MSE sector and how the entrepreneurs have responded to those constraints. Qualitative data was collected. The research design used quantitative and qualitative techniques.

\section{The Study Population}

The population for the survey involved in this study consisted of 2,990 entrepreneurs in the MSEs sector in Kisii county operating in Suneka market, Keroka market and DarajaMbili Market for more than two years.

\section{Sample Size and Sampling Techniques}

The survey used simple random sampling technique. Stratified random sampling technique was used in selecting Keroka Market, Suneka market and DarajaMbili markets. This technique enabled us to generalize 
findings and make inferences from the sample, thus enabling us to draw conclusions. The sampling frame comprised 2,990 micro and small enterprise entrepreneurs operating in Kisii County. This technique was used to group population into homogeneous subsets that share similar characteristics and ensure equitable representation of the population. It should be noted that darajaMbili market, Suneka and Keroka markets operates almost in the same manner save for the days they operate.

\section{Data Collection}

The data was obtained from primary sources which included direct interaction and interview schedules with various respondents; and secondary sources mainly from books, research dissertations, publications of Kenya Central Bureau of statistics (CBS), journals, other documents on MSEs, and entrepreneurship related literature.

\section{Instrumentation}

In this research process three methods were used namely: interviews, discussion and observations.

The interview schedule was the main method used to collect primary data. Both open-ended and structured questionnaires were administered. The interview schedule was administered by researcher. A discussion was held to assess what were considered as major constraints for SMEs in their area of business. Observation method was adopted for clarifying information received from the respondents.

\section{Validity and Reliability}

Validity is the degree to which the method of collecting information results in accurate information and the instruments for data collection should be as accurate as possible. To ensure that the data gathered was valid and reliable, instruments were pilot tested in the field and necessary adjustments made before embarking on recording of the final data collected.

The instrument was pre-tested using approximately $10 \%$ of the respondents. Reliability was assessed using the Kuder-Richardson (K-R 21) formulae to determine the degree of consistency and accuracy of the instruments.

\section{Data Analysis.}

Data from the respondents was analyzed and translated into useful information using percentages and the statistical package for social sciences (SPSS). Frequency distributions and tables were used to draw conclusions.

\section{Introduction}

\section{Findings And Discussion}

This chapter presents data analysis and discusses key findings.

\section{Marital Status of the Respondents}

Majority of the respondents $70 \%$ were married and only $30 \%$ were single. This suggests that married people are more motivated to operate businesses in order to meet the many challenges of the family. This is due to the fact that married women are able to get collateral from the husbands considering that most properties are in the name of men.

\section{Marital status of the respondents (N200)}

\begin{tabular}{|c|c|c|}
\hline Status & Frequency & Percent \\
\hline Married & 140 & 70 \\
\hline Single & 60 & 30 \\
\hline Total & 200 & 100 \\
\hline
\end{tabular}

Source: Researcher, 2013.

\section{Source of finance}

Personal savings are the main source of finance at 50\% for the women entrepreneurs interviewed. Rotating Savings and Credit Association (ROSCAS)/ merry-go-round groups were the other source where most women turn for finance at $25 \%$ respondents, while the banks funded only $10 \%$ depicting the conditions of security as the missing factor to lend. Other sources of finance were the spouse as indicated early that most of the women involved in the MSEs were married women. This scenario seems to highlight that MSEs have problems in acquiring credit for business start up or expansion from banks. 
Sources for finance $(N=200)$

\begin{tabular}{ccc}
\hline Main source of finance & Frequency & Percent \\
\hline Personal savings & 100 & 50 \\
Borrowed from merry-go-round(ROSCAS) & 50 & 25 \\
Borrowed from banks & 20 & 10 \\
Sponsored by spouse & 30 & 15 \\
\hline
\end{tabular}

Source: Researcher, 2013.

Ranking of Constraints by women entrepreneurs

Table below shows how women entrepreneurs have ranked their respective perceived constraints.

Core constraints and their ranking $(N=200)$

\begin{tabular}{ccc}
\hline Main source of finance & Frequency & Percent \\
\hline Finance & 100 & 50 \\
Security/Collateral & 50 & 25 \\
Legal framework & 50 & 25 \\
\hline
\end{tabular}

\section{Source: Researcher, 2013.}

$50 \%$ of the women entrepreneurs rated finance as the most severe constraint affecting their performance, followed by lack of security/collateral at $25 \%$ and legal constraint also at $25 \%$.

\section{Entrepreneurs' Response to the Constraints}

Having examined some of the constraints to performance experienced by entrepreneurs operating MSEs in Kisii County, the study investigated their responses to the constraints. The study reveals that entrepreneurs have approached and employed different strategies in response to the constraints facing them.

Entrepreneurs Response to the constraints
\begin{tabular}{|l|l|c|c|}
\hline \multicolumn{1}{|c|}{ Constraint } & \multicolumn{1}{|c|}{ Response } & \multicolumn{1}{c|}{$\begin{array}{c}\text { Frequency } \\
(\mathbf{N}=\mathbf{2 0 0})\end{array}$} & 60 \\
\hline collateral constraint & $\begin{array}{l}\text { Porrowed from husband, used husband } \\
\text { title deeds }\end{array}$ & 30 \\
\hline Finance constraint & $\begin{array}{l}\text { Borrowed more working capital from } \\
\text { family \& friends and Joined business } \\
\text { associations, groups, ROSCAS }\end{array}$ & 35 \\
\hline Legal Constraint & $\begin{array}{l}\text { Acquired necessary trade licenses, used } \\
\text { husband name }\end{array}$ & 70 & 35 \\
\hline
\end{tabular}

Source: Researcher, 2013.

Most women (30\%) resorted to borrowing from husband the collateral for securing finance and using husband title deeds and other properties in securing collateral. 35\% have joined informal self-help groups commonly referred to as 'merry-go-round' for finance and $35 \%$ have used husband names and use husbands to acquire the length licenses.

\section{Introduction}

\section{Summary, Conclusion And Recommendations}

From an enumerated population of 2,990 entrepreneurs, a sample of 200 was selected randomly and a survey was conducted on this sample using both structured and un-structured questionnaire. Data from the respondents was analyzed and translated into useful information using the Statistical Package for Social Sciences (SPSS)

From the findings, out of the total sample of 200 respondents 140 of them $70 \%$ women were married while 60 of the women a 30\% were single. Marital status has been shown as an important factor to finance and control of the business, especially in cases where the husband has either provided the capital or collateral to secure it. In many cases the wife may operate the business but the husband makes the decision and controls the money. This is not good for business. This suggests that besides the external forces that militate against women's enterprises, forces within the household, particularly the marriage union, constitute a contributor to the stability and growth of women owned enterprises and their development in Kenya.

From the study, several constraints that influence the performance of entrepreneurs in MSEs in Kisiicounty were identified and include: low capital investment, regulatory framework, lack of collateral and socio-cultural beliefs and practices.

Most entrepreneurs in this study displayed limited knowledge in areas such as access to financial information and access to legal aspects of conducting the business save for the regular visits from the Municipal 
councils attendants who come for payments of tickets for operating a business in an open area which is different from a modern and highly competitive business environment.

Lack of access to finance was indicated as a key problem for the entrepreneurs. Problems associated with lack of finance include the stringent collateral requirements. The main reason for entrepreneurs turning to their spouses or merry-go rounds schemes was to seek affordable financial support without necessarily providing collateral as security for borrowing.

Regulatory requirements, according to the respondents, are not only expensive but cumbersome too. Various licenses, permits and certifications are mandatory to operate a business. Local authorities demand trade licenses; the Ministry of Public Health requires health certificates for those handling edible products, the Kenya tourism Board demands restaurants to be licensed by them, the National Environmental Management Authority (NEMA) must issue a permit after a thorough assessment of waste disposal mechanisms and in some cases, a certificate of good conduct from the Kenya Police force.

Whereas some of these requirements may be necessary, others simply add up to the cost of operation and the process of obtaining some of them is itself cumbersome and a waste of useful time that could be better employed in the business. Accordingly, business licensing imposes costs on businesses that are often out of proportion to the resultant benefits. Further, in practice, the regulatory provisions are abused and have become merely income earning opportunities for those charged with enforcing the regulations.

This has resulted in a number of traders evading licenses, and therefore flouting regulations laid down by authorities.

In-spite of all these challenges, women entrepreneurs in Kisii County have managed to cope with them by employing various strategies and survival tactics like incorporating their husbands in the business, diversifying in business, joining or forming informal business associations.

The study recommends that the government through the municipal and town councils to reduce the number of the required licenses and the period taken for some of the licenses to be available and the number of offices one has to visit before they are allowed to conduct the business.

The study suggests that financial institutions should look for other means of securing the loans and other facilities they offer to women without necessarily looking at the collateral as most of it is with the husbands who may not be willing to give it to their wives for acquiring loans.

\section{References}

[1] G.o.K (2008). Economic Survey of Kenya. Nairobi: Government Printer Press

[2] Gray, C. (2002). Entrepreneurship Resistance to Change and Growth in Small Firms: Journal of Small Business and Enterprise Development, 9(1), pp. 61-72.

[3] Edgar Online Inc. (2003). California Pizza Kitchen operations: Report on Management operations. Califonia Finance Magazine, pp.6-9.

[4] Government of Kenya (2009). Economic Survey. Nairobi: Government Printer.

[5] Government of Kenya (2007).Assistance to micro and small and medium enterprisesProgramme: A Ministry of Trade Initiative. Nairobi: Government Printer.

[6]Central Bureau of Statistics (1993).National Micro and Small Enterprise Baseline Survey.Nairobi:Government Printer.

[7] Naituli, G.,Wegulo, Francis N. \&Kaimenyi, B. (2006). Entrepreneurial Human Capital and Growth of Micro and Small Scale Women enterprises in Rural Kenya.

[8] K-REP, (1995). Employment and income in micro and small enterprises in Kenya.Results of a 1995 Survey. Research Paper No. 26. Nairobi

[9] Bosire, J. \& M Etyang (2003). The effect of education on business skills cognition: the case of indigenous microscale enterprise owners in Kenya. Journal of Vocational Education \& Training, Volume 55, Issue 1 March 2003, pages 5-20.

[10] Osoro K.M (2013)The Effects of Financial Institutions Intervention on the Growth of small Enterprises in kenya: A Survey of public service transporters in KisiiMunicipalityInterdisplinary journal of contemporary research in Business 159 MAY 2013 VOL 5, NO 1

[11] Cassar, G., Holmes, S. (2003), "Capital structure and financing of SMEs: Australian evidence", Accounting and Finance, Vol. 43 pp.123-47.

[12] Gregory, B.T., Rutherford, M.W., Oswald, S., Gardiner, L. (2005), "An empirical investigation of the growth cycle theory of small firm financing", Journal of Small Business Management, Vol. 43 No.4, pp.382-92.

[13] Kithyo, I., Kipkurui, L. Okemwa\& P. Korir, J. (2004). Modernization in automotive technology and performance of informal sector mechanics.:CIGR Journal of Scientific Research and Development. Invited Overview Paper, VI.; MoiUniversity.

[14] Hussain, J.G., Matlay, H. (2007), "Financing preference of ethnic minority SMEs", Journal of Small Business and Enterprise Development,

[15] Matlay, H. (2004), "Small tourism firms in e-Europe: definitional, conceptual and contextual considerations", in Thomas, R. (Eds),Small Firms in Tourism: International Perspectives, Elsevier, Oxford, pp.297-312.

[16] Osoro K \&Muturi W. (2013).The Role Of Micro Financial Institutions On The Growth Of Smes In Kenya:A Case Study Of Micro Financial Institutions In Kisii Town. IOSR Journal Of Humanities And Social Science (IOSR-JHSS) Volume 16, Issue 1 (Sep. - Oct. 2013), PP 83-93 